ISSN 2616-7328 (Online); ISSN 2409-904X (Print)

Kitaêznavčì doslìdžennâ, 2020, No. 1, pp. 17-26

doi: https://doi.org/10.15407/chinesest2020.01.017

UDC 338.012:338.24.021.8

\title{
ENERGY TRANSFORMATION IN CHINA: TOWARDS GLOBAL LEADERSHIP IN RENEWABLE ENERGY
}

\section{O. Drobotiuk}

Ph.D. in Economics,

Kyiv National Economic University named after Vadym Hetman

Institute for Contemporary China Studies named after Borys Kurts

03057, Kyiv, 54/1 Peremohy prospect

khomenko@kneu.edu.ua

\section{Osadchuk}

Kyiv National Economic University named after Vadym Hetman Institute for Contemporary China Studies named after Borys Kurts 03057, Kyiv, 54/1 Peremohy prospect

leradmn@ukr.net

\section{Shaidetska}

Kyiv National Economic University named after Vadym Hetman Institute for Contemporary China Studies named after Borys Kurts 03057, Kyiv, 54/1 Peremohy prospect

shaidvar@gmail.com

Global climate change, scarcity of natural resources and the global trend of sustainable development have led to the transformation of the energy sector. Moreover, the balanced management of natural resources is one of the critical challenges for governments around the world. Renewable energy is the way to overcome the shortage of traditional energy sources and reduce carbon dioxide emissions into the environment. It is the development of renewable energy and access to low-cost, reliable, sustainable and modern energy sources that is one of the seventeen sustainable development goals adopted by the UN in 2015.

China's rapid economic development, which began 40 years ago with a comprehensive reform policy, has led to a growing demand for energy. Since 1978, the Chinese government has introduced many measures to attract investment and restructure the energy sector. In 2018, according to the international organization Enerdata, China ranked first in energy production, sales and consumption, ahead of the United States and Japan.

The growth rate and size of the Chinese economy require significant energy consumption, so along with the preservation of traditional energy sources, China is actively increasing the generation of electricity from renewable sources, mainly solar and wind. Statistics show that China has a leading position in the field of renewable energy and is the largest investor in it. China has the highest share of solar energy consumption in the world, and wind energy is the second most important renewable energy in the country. It is in these sectors of renewable energy that most specialists are employed. China has significant

(C) 2020 O. Drobotiuk, V. Osadchuk and V. Shaidetska; Published by the A. Yu. Krymskyi Institute of Oriental Studies, NAS of Ukraine and the Ukrainian Association of Sinologists on behalf of The Chinese Studies. This is an Open Access article distributed under the terms of the Creative Commons Attribution License (https://creativecommons.org/licenses/by-nc-nd/4.0/). 
investment resources for the further development of renewable energy, which meets the national goal.

The article presents a retrospective analysis of China's energy sector transformation, a description of the current state of production and consumption of traditional and renewable energy.

Keywords: China, green energy, renewable energy, energy transformation, green growth, low carbon economy

\section{ЕНЕРГЕТИЧНА ТРАНСФОРМАЦІЯ В КИТАЇ: ШЛЯХ ДО ГЛОБАЛЬНОГО ЛІДЕРСТВА В АЛЬТЕРНАТИВНІЙ ЕНЕРГЕТИЦІ}

\section{О. В. Дроботюк, В. С. Осадчук, В. О. Шайдещьька}

В умовах загострення глобальної проблеми дефіциту природних ресурсів альтернативні джерела енергії набувають стратегічного значення для країн світу у боротьбі з енергетичною кризою, забрудненням довкілля та у забезпеченні сталого розвитку. Як одна з найбільших економік світу із швидкою індустріалізацією та рівнем урбанізації, що зростає, Китай посідає перші позиції за виробництвом та споживанням енергії (табл. 1).

Таблиия 1

Місце КНР у глобальній енергетиці, 2018 р.

\begin{tabular}{|c|c|c|c|c|c|c|c|c|}
\hline \multirow[t]{2}{*}{ № } & \multicolumn{2}{|c|}{ Виробництво } & \multicolumn{2}{|c|}{ Споживання } & \multicolumn{2}{|c|}{$\begin{array}{l}\text { Зовнішній торго- } \\
\text { вельний баланс } \\
\text { (енергетичний) }\end{array}$} & \multicolumn{2}{|c|}{$\begin{array}{c}\text { Частка відновлюва- } \\
\text { них джерел у вироб- } \\
\text { ництві електроенергії }\end{array}$} \\
\hline & країна & $\begin{array}{c}\text { мЛН } \\
\text { т.н.е. }\end{array}$ & країна & $\begin{array}{c}\text { млН } \\
\text { т.н.е. }\end{array}$ & країна & $\begin{array}{c}\text { мЛН } \\
\text { т.н.е. }\end{array}$ & країна & $\%$ \\
\hline 1 & КHP & 2534 & КНР & 3164 & КНP & 693,8 & Норвегія & 97.88 \\
\hline 2 & США & 2175 & США & 2258 & Японія & 392,3 & Нова Зеландія & 83.07 \\
\hline 3 & РФ & 1492 & Індія & 929 & Індія & 346,0 & Бразилія & 82.46 \\
\hline 4 & $\begin{array}{l}\text { Саудівська } \\
\text { Аравія }\end{array}$ & 676 & РФ & 800 & $\begin{array}{l}\text { Південна } \\
\text { Корея }\end{array}$ & 260,3 & Колумбія & 75.73 \\
\hline 5 & Індія & 588 & Японія & 424 & Німеччина & 198,8 & Венесуела & 70.77 \\
\hline 6 & Канада & 526 & $\begin{array}{l}\text { Південна } \\
\text { Корея }\end{array}$ & 307 & Італія & 120,7 & Канада & 65.86 \\
\hline 7 & Індонезія & 441 & Німеччина & 301 & Франція & 116,9 & Швеція & 55.27 \\
\hline 8 & Австралія & 426 & Канада & 301 & Туреччина & 110,3 & Португалія & 52.18 \\
\hline 9 & Іран & 418 & Бразилія & 290 & $\begin{array}{l}\text { Тайвань } \\
\text { (КНР) }\end{array}$ & 105,9 & Чилі & 46.84 \\
\hline 10 & Бразилія & 292 & Іран & 265 & Іспанія & 102,0 & Румунія & 41.27 \\
\hline
\end{tabular}

За оцінками китайських вчених, тривалість експлуатації ресурсів вугілля, нафти та природного газу в Китаї становить менше 100, 15 та 30 років відповідно [Zhao, Zhang, Hubbard, \& Yao 2013]. Враховуючи попит на енергетику та ресурсний потенціал країни, уряд КНР прийняв ряд заходів для розвитку альтернативної енергетики. Тому протягом останнього десятиліття енергетична галузь досягла значного прогресу для прискорення стійких інновацій в енергетиці. Вітрова та сонячна фотоелектрична промисловість, лідером в яких є Китай, продемонстрували свою здатність знижувати енерговитрати за останні 10 років. Світова базова ціна на сонячну енергію знизилася на 84 \%, а 
на вітрову - на понад 50 \%, порівнюючи з 2010 роком. Вітрова та сонячна енергія почали в середньому в усьому світі випереджати новостворене виробництво електроенергії на викопному паливі за вартістю. У багатьох частинах світу вартість енергії від вітрових та сонячних фотоелектричних батарей зараз нижча, ніж у нових вугільних та газових установок. Тим часом ціна зберігання літій-іонних акумуляторів знизилася приблизно на $85 \% 3$ 2012 року.

Табличя 2

Глобальні лідери в альтернативній енергетиці у 2018 році

\begin{tabular}{|c|c|c|c|c|c|}
\hline Показники & $\begin{array}{l}\text { Перше } \\
\text { місце }\end{array}$ & $\begin{array}{l}\text { Друге } \\
\text { місце }\end{array}$ & $\begin{array}{l}\text { Третє } \\
\text { місце }\end{array}$ & $\begin{array}{l}\text { Четверте } \\
\text { місце }\end{array}$ & $\begin{array}{l}\text { П'яте } \\
\text { місце }\end{array}$ \\
\hline $\begin{array}{l}\text { Інвестиції у відновлювані } \\
\text { джерела енергії та палива } \\
\text { (без врахування гідроенергії } \\
\text { понад } 50 \text { МВт) }\end{array}$ & Китай & США & Японія & Індія & Австралія \\
\hline $\begin{array}{l}\text { Інвестиції у відновлювані } \\
\text { джерела енергії та паливо на } \\
\text { одиницю ВВП }\end{array}$ & Палау & Джибуті & Марокко & \multicolumn{2}{|c|}{ Ісландія/Сербія } \\
\hline $\begin{array}{ll}\text { Потужність } \\
\text { енергетики }\end{array}$ & Туреччина & Індонезія & США & Ісландія & $\begin{array}{l}\text { Нова Зе- } \\
\text { ландія }\end{array}$ \\
\hline Потужність гідроенергетики & Китай & Бразилія & Пакистан & Туреччина & Ангола \\
\hline $\begin{array}{l}\text { Потужність сонячної фото- } \\
\text { вольтаїки (PV) }\end{array}$ & Китай & \multicolumn{2}{|c|}{ Індія/США } & Японія & Австралія \\
\hline $\begin{array}{l}\text { Потужність сонячної тепло- } \\
\text { вої енергетики (CSP) }\end{array}$ & \multicolumn{2}{|c|}{ Китай/Марокко } & $\begin{array}{l}\text { Південна } \\
\text { Африка }\end{array}$ & $\begin{array}{c}\text { Саудівська } \\
\text { Аравія } \\
\end{array}$ & - \\
\hline $\begin{array}{l}\text { Потужність вітрової енерге- } \\
\text { тики }\end{array}$ & Китай & США & $\begin{array}{l}\text { Німеччи- } \\
\text { на }\end{array}$ & Індія & Бразилія \\
\hline $\begin{array}{l}\text { Потужність сонячних водо- } \\
\text { нагрівачів }\end{array}$ & Китай & Туреччина & Індія & Бразилія & США \\
\hline Виробництво біодизеля & США & Бразилія & Індонезія & $\begin{array}{l}\text { Німеччи- } \\
\text { на }\end{array}$ & Аргентина \\
\hline Виробництво етанолу & США & Бразилія & Китай & Канада & Таїланд \\
\hline
\end{tabular}

Джерело: [REN21 2019]

У сучасних умовах спостерігається тенденція до прискореного енергетичного переходу у багатьох провідних країнах світу, і в Китаї зокрема. У 2019 році Міжнародне енергетичне співтовариство Всесвітнього економічного форуму в Китаї висвітлило багато прикладів нових, корисних для суспільства інновацій у енергетичному секторі, які сприяють прискоренню енергетичного переходу. Метою більшості створених інновацій є скорочення викидів, енергоефективність, системна ефективність, інтеграція відновлюваних джерел енергії та доступ до електроенергії [World Economic Forum 2020].

У своїй роботі “Characteristics of China's Energy Transformation” Чжу та Ван виокремлюють три характерні особливості енергетичної трансформації КНР: 1) Китай вступив в еру вугілля в 1960-х роках, що є на 100 років пізніше, аніж Німеччина та на 80 років пізніше, аніж США; 2) розподіл відновлюваних джерел енергії в КНР не відповідає рівню споживання, та центр розподілу ресурсів відокремлений від центру споживання енергії; 3) споживання енергії в Китаї ще перебуває у стадії зростання через індустріалізацію та урбанізацію [Zhu\&Wang 2019]. 
Перша та третя тези, які були висунуті Чжу і Ван, підтверджуються статистичними даними про сучасний розподіл виробництва енергії. Так, згідно 3 річними статистичними звітами про глобальну енергетику, що видаються консалтинговою компанією у енергетичній галузі Enerdata, більше 70 \% видобутку припадає на вугілля (рис. 1-2). Китай є найбільшим споживачем первинної енергії у світі, його частка становить 48 \% у світовому споживанні вугілля та лігніту (61\% - від національного обсягу).

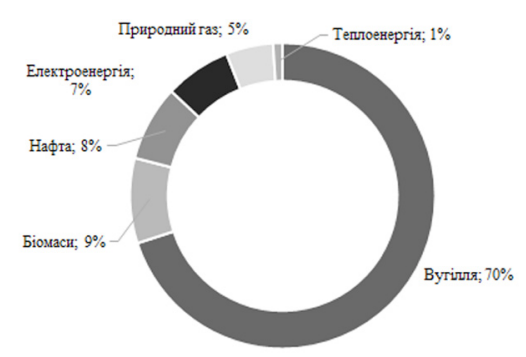

Джерело: [Enerdata 2017]

Рис. 1. Розподіл виробництва енергії за енергоносіями КНР у 2016 р., \%

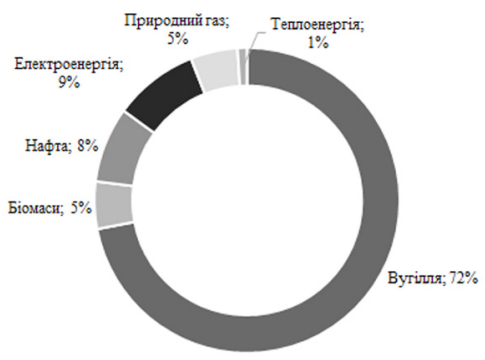

Джерело: [Enerdata 2019]

Рис. 2. Розподіл виробництва енергії за енергоносіями КНР у 2018 р., \%

Разом із збереженням частки традиційних джерел енергії у структурі енергетичної галузі Китаю зростає виробництво альтернативної енергії - частка генерації електроенергії з відновлюваних джерел у 2018 р. становила 26,3 \% (рис. 3).

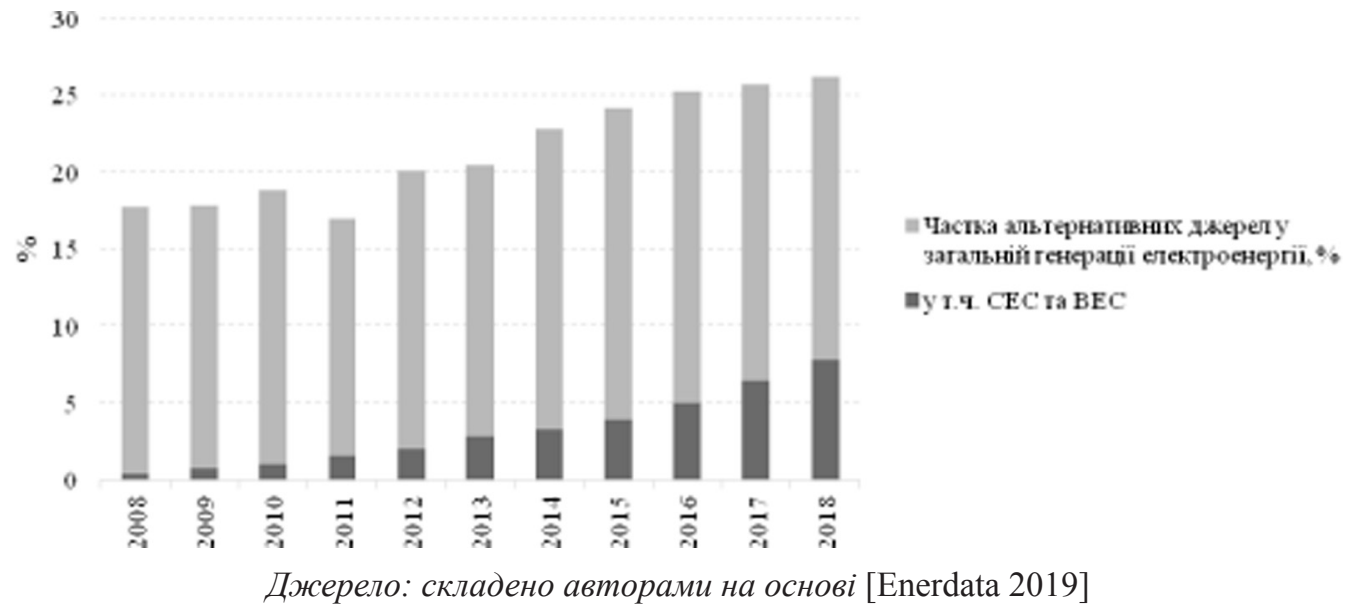

Рис. 3. Динаміка виробництва альтернативної електроенергії КНР, \% загального виробництва електроенергії

Суттєві досягнення Китай має у генерації енергії з відновлюваних джерел, зокрема він $€$ лідером за встановленою потужністю гідроелектростанцій (ГЕС), сонячних та вітрових електростанцій (СЕС, ВЕС). За оцінками Міжнародного агентства з відновлюваної енергетики, за встановленою потужністю альтернативної енергетики Китай посідає перше місце (696,87 ГВт), випереджаючи США (245,25 ГВт), Бразилію (135,67 ГВТ), Німеччину (120,01 ГВт) й Індію (117,92 ГВт) [IRENA 2019].

За даними Міжнародного енергетичного агентства, Китай є найбільшим виробником сонячних фотомодулів - 73 \% глобального ринку припадає на 
китайських виробників (6 \% - на Південну Корею, 5 \% - на Малайзію, 3 \% на країни (C) [IEA 2019]. Як результат, у Китаї розміщені найпотужніші CEC:

- Golmud Desert Solar Park (потужність 4,5 ГВт),

- Haixi Delingha Solar Park (2 ГВт),

- Pavagada Solar Park (2 ГВт),

- Tengger Desert Solar Park (1,5 ГВТ),

- Jinchuan, Gansu (1 ГВТ $)^{1}$.

Згідно $з$ даними Bloomberg New Energy Finance, до найбільших світових виробників вітрогенераторів у 2018 році (за введеною потужністю) належать Goldwind (6,66 ГВт) - друга позиція після Vestas (10,09 ГВт, Данія), Envision п'ята (3,28 ГВт), Ming Yang - сьома (2,44 ГВт), Nordex - восьма (2,43 ГВт), Guodian UP - дев'ята (1,29 ГВт), Windey - десята (0,94 ГВт) [Bloomberg New Energy Finance 2019].

Не останнє місце у таких вражаючих результатах посідає державна політика у секторі альтернативної енергетики. Сучасна політика китайського уряду в енергетичній галузі спрямована на зростання ролі альтернативних джерел енергії. Підгрунтям для цього є: 1) вичерпаність традиційних ресурсів; 2) загострення екологічної кризи в КНР та світі в цілому; 3) відносно низька вартість експлуатації.

Розвиток альтернативної енергетики в КНР розпочався із сільського господарства. Так, до 1990-х років керівні принципи були спрямовані саме на розбудову енергетичної складової сільського господарства у зв'язку з дефіцитом палива, який виник у галузі. 3 1990-х до середини 2000-х поступово почали з'являтися спеціалізовані програми та закони в секторі альтернативної енергетики та ті, що стосувалися вирішення проблем забруднення повітря. Серед найбільш важливих - Закон про відновлювану енергію, що почав діяти у 2005 році, до якого у 2009 році було внесені зміни. Окрім законів, у Китаї розробили низку п'ятирічних планів, середньо- та довгострокових стратегій, в яких викладено основні положення та принципи розвитку альтернативної енергетики [Liu 2019].

\section{Ключові нормативно-правові акти з розвитку альтернативної енергетики в КНР}

Таблиия 3

\begin{tabular}{|c|c|c|}
\hline Рік & $\begin{array}{l}\text { Програма, план, } \\
\text { стратегія, закон }\end{array}$ & Ключові положення \\
\hline \multirow[t]{2}{*}{1995} & $\begin{array}{l}\text { Керівництво з розвитку } \\
\text { нової і відновлюваної } \\
\text { енергії в Китаї }\end{array}$ & $\begin{array}{l}\text { Визначення пріоритетних напрямів розвитку віднов- } \\
\text { люваної енергетики, майбутніх завдань, ризиків. }\end{array}$ \\
\hline & $\begin{array}{l}\text { Закон про електроенер- } \\
\text { гію }\end{array}$ & $\begin{array}{l}\text { Заохочення та підтримка державою виробництва елек- } \\
\text { троенергії за рахунок використання відновлюваних } \\
\text { джерел (ст. 5). }\end{array}$ \\
\hline \multirow[t]{2}{*}{2001} & $\begin{array}{l}\text { Національний план за- } \\
\text { хисту довкілля }\end{array}$ & $\begin{array}{l}\text { Інтенсивний розвиток технологій альтернативної } \\
\text { енергї̈-вітрової, сонячної, біоенергетики. }\end{array}$ \\
\hline & $\begin{array}{l}\text { 10-й П’ятирічний план } \\
\text { енергозбереження та } \\
\text { комплексного викорис- } \\
\text { тання ресурсів }\end{array}$ & $\begin{array}{l}\text { Підвищення енергоефективності на основі енергозбе- } \\
\text { реження і зменшення споживання, а також комплек- } \\
\text { сного використання ресурсів. }\end{array}$ \\
\hline
\end{tabular}

${ }^{1}$ Станом на червень 2019: https:/www.statista.com/statistics/217265/largest-solar-pv-powerplants-in-operation-worldwide/ 


\begin{tabular}{|c|c|c|}
\hline \multirow[t]{2}{*}{2005} & $\begin{array}{l}\text { Закон про альтернативні } \\
\text { джерела енергії Китай- } \\
\text { ської Народної Республі- } \\
\text { ки }\end{array}$ & $\begin{array}{l}\text { Сприяння розвитку та використанню відновлюваної } \\
\text { енергії, збільшення енергопостачання, покращення } \\
\text { енергетичної структури, забезпечення енергетичної } \\
\text { безпеки, захист довкілля та досягнення сталого еконо- } \\
\text { мічного та соціального розвитку. }\end{array}$ \\
\hline & $\begin{array}{l}\text { Керівні принципи з роз- } \\
\text { витку альтернативної } \\
\text { енергетики }\end{array}$ & $\begin{array}{l}\text { Встановлення цілей промислового розвитку у галузі } \\
\text { енергетики, у т. ч. вітрової, геліо-, гідро-, біоенергети- } \\
\text { ки. }\end{array}$ \\
\hline \multirow[t]{3}{*}{2006} & $\begin{array}{l}\text { Національний довгостро- } \\
\text { ковий план розвитку на- } \\
\text { уки і технологій у віднов- } \\
\text { люваній енергії }\end{array}$ & $\begin{array}{l}\text { Здійснення прориву в енергозберігаючих технологіях } \\
\text { та “зеленій” енергетиці }\end{array}$ \\
\hline & $\begin{array}{l}\text { Правила управління роз- } \\
\text { поділом цін та витрат на } \\
\text { виробництво відновлюва- } \\
\text { ної енергії }\end{array}$ & $\begin{array}{l}\text { Встановлення ціни на електроенергію та розподіл ви- } \\
\text { трат. } \\
\text { Зобов'язання на придбання відновлюваної енергії у } \\
\text { національній мережі, або на основі державної фіксо- } \\
\text { ваної ціни чи ціни уряду. }\end{array}$ \\
\hline & $\begin{array}{l}\text { Правила управління ви- } \\
\text { робництвом відновлюва- } \\
\text { ної енергії }\end{array}$ & $\begin{array}{l}\text { Управління програмами генерації, визначення відпо- } \\
\text { відальності енергетичних підприємств. }\end{array}$ \\
\hline \multirow[t]{2}{*}{2007} & $\begin{array}{l}\text { Середній та довгостроко- } \\
\text { вий план розвитку альтер- } \\
\text { нативної енергетики КНР } \\
\text { до } 2020 \text { року. }\end{array}$ & $\begin{array}{l}\text { Стратегічний пріоритет - розвиток альтернативної } \\
\text { енергетики задля досягнення сталого розвитку, енер- } \\
\text { гетичної безпеки; прискорення розробки та впров-- } \\
\text { дження технологій у сонячній, вітровій, біо-, та гідро- } \\
\text { енергії; забезпечення конкурентоспроможності ринку } \\
\text { відновлюваної енергетики; збільшення частки альтер- } \\
\text { нативних джерел енергії в Китаї. }\end{array}$ \\
\hline & $\begin{array}{l}\text { 11-й П’ятирічний план } \\
\text { розвитку альтернативної } \\
\text { енергії }\end{array}$ & $\begin{array}{l}\text { Збільшення частки відновлюваної енергії у структурі } \\
\text { виробництва та споживання; розробка гідроенергетич- } \\
\text { них баз; прискорення будівництва АЕС; енергозбере- } \\
\text { ження та захист довкілля. }\end{array}$ \\
\hline 2011 & $\begin{array}{l}\text { 12-й П'ятирічний план } \\
\text { розвитку альтернативної } \\
\text { енергетики 2011-2015 }\end{array}$ & $\begin{array}{l}\text { Зниження споживання енергії на одиницю ВВП на } \\
16 \text { \%; збільшення споживання енергії з нетрадиційних } \\
\text { джерел до 11,4 \%; зниження інтенсивності вуглецю на } \\
17 \text { \%. }\end{array}$ \\
\hline 2016 & $\begin{array}{l}\text { 13-й П'ятирічний план } \\
\text { розвитку альтернативної } \\
\text { енергетики 2016-2020 }\end{array}$ & $\begin{array}{l}\text { Збільшення споживання енергії з альтернативних } \\
\text { джерел з } 12 \text { \% у } 2015 \text { р. до } 15 \text { \% у } 2020 \text { р. та до } 20 \% \\
\text { у } 2030 \text { р.; збільшення встановленої потужності нетра- } \\
\text { диційних джерел енергії до } 680 \text { ГВт до } 2020 \text { року; роз- } \\
\text { виток технологій у видобутку енергії океану }\end{array}$ \\
\hline
\end{tabular}

Джерело: складено авторами на основі [Хоменко, Тимченко 2017], [Liu 2019]

Окрім урядової політики, ще одним із найбільш важливих рушіїв зростання частки відновлюваної енергії у структурі енергетики Китаю є інвестиції. За даними Bloomberg New Energy Finance, у 2019 році глобальні інвестиції в альтернативну енергетику становили 282,2 млрд дол. [Bloomberg New Energy Finance 2019]. Майже 30 \% сукупного обсягу інвестицій припадає на КНР, 19,9 \% - на США та 5,8 \% - на Японію. Зокрема, у 2019 році китайські інвестиції у відновлювану енергетику становили 83,4 млрд дол. Однак спостерігається тенденція скорочення обсягу інвестицій - у 2019 році на $9 \%$ менше, порівнюючи 3 попереднім роком (рис. 4). У розрізі сегментів, інвестиції у 
вітрову генерацію збільшилися на 10 \% до 55 млрд дол., проте зменшилися в сонячну на $33 \%$ до 25,7 млрд дол.

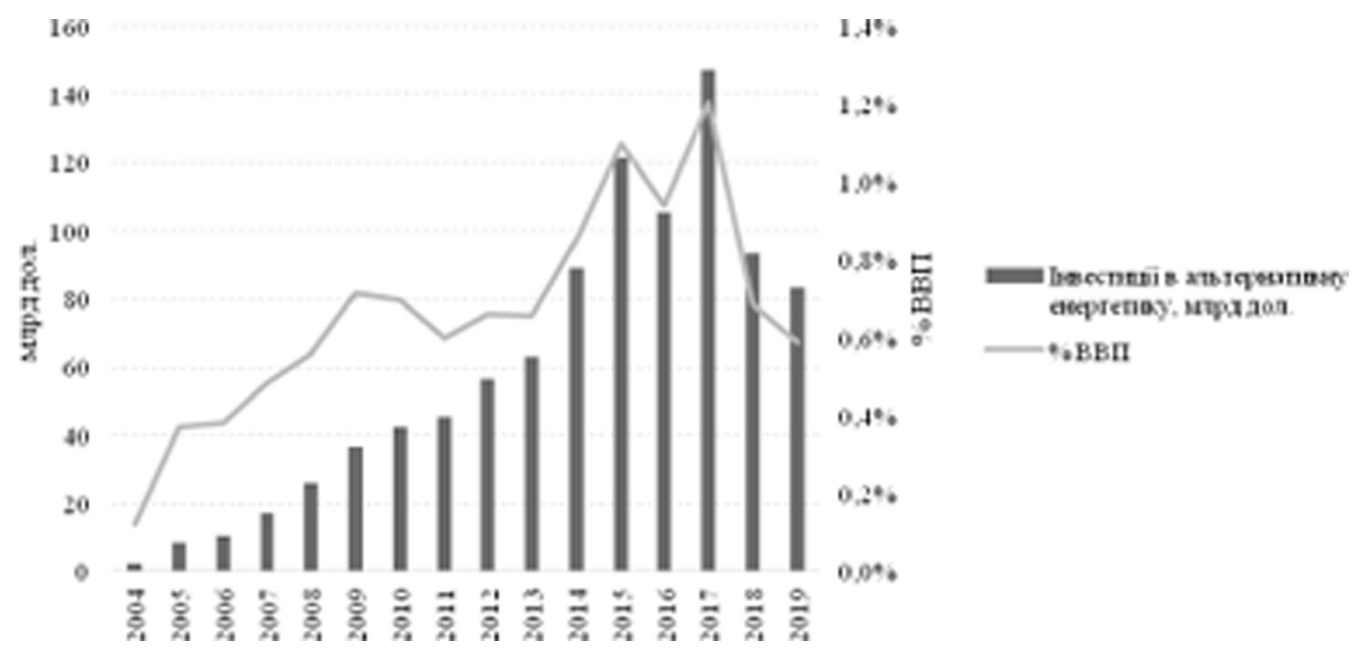

Джерело: складено авторами на основі International Renewable Energy Agency, UNCTAD

Рис. 4. Інвестиції в альтернативну енергетику КНР, млрд дол.

На сьогоднішній день перед урядом КНР стоїть завдання досягти абсолютного середньозаможного суспільства до кінця 2020 року, однак це не просто подолання бідності та забезпечення соціальних стандартів, але і підвищення якості життя населення. Тому, враховуючи розміри китайської економіки, динаміку іiі зростання та потреби у іiї енергозабезпеченні, розвиток альтернативної енергетики $є$ важливим стратегічним кроком у досягненні цілей уряду. Також варто зазначити, що статистична дані підтверджують глобальне лідерство КНР у відновлюваній енергетиці, зокрема сонячній та вітровій генерації.

\section{ЛІТЕРАТУРА}

Bloomberg New Energy Finance. Late Surge in Offshore Wind Financings Helps 2019 Renewables Investment to Overtake 2018 [Електронний ресурс] // Bloomberg New Energy Finance. 2019. Режим доступу: https://about.bnef.com/ blog/late-surge-in-offshore-wind-financings-helps-2019-renewables-investmentto-overtake-2018/.

Enerdata. Global Energy Statistical Yearbook 2017 [Електронний ресурс] // Enerdata. 2017. Режим доступу: https://yearbook.enerdata.net/2016/.

Enerdata. Global Energy Statistical Yearbook 2019 [Електронний ресурс] // Enerdata. 2019. Режим доступу: https://www.enerdata.net/publications/worldenergy-statistics-supply-and-demand.html.

IEA. IEA-PVPS - Trends in Photovoltaic Applications 2019 [Електронний peсурс] // IEA. 2019. Режим доступу: https://www.dropbox.com/s/t6j1vw8dmd05kv6/Iea-pvps_report_2019.pdf.

IRENA. Renewable capacity statistics 2019 [Електронний ресурc] // IRENA. 2019. Режим доступу: https://www.irena.org/publications/2019/Mar/RenewableCapacity-Statistics-2019.

Liu J. China's renewable energy law and policy: A critical review // Renewable and Sustainable Energy Reviews, 2019, № 99. 
REN21. Renewables 2019 Global Status Report [Електронний ресурс] // REN21. 2019. Режим доступу: https://www.ren21.net/wp-content/uploads/2019/ 05/gsr_2019 full_report en.pdf.

World Economic Forum. Global Innovations from the Energy Sector 2010-2020 [Електронний ресурс] // World Economic Forum. 2020. Режим доступу: http:// www3.weforum.org/docs/WEF_Transformational_Energy_Innovations_2010 2020.pdf.

Zhao Z., Zhang S.-Y., Hubbard B., Yao B. The emergence of the solar photovoltaic power industry in China // Renewable and Sustainable Energy Reviews, 2013, № 21 .

Zhu T., Wang L. Characteristics of China's Energy Transformation // State Energy Transition. Beijing, 2019.

Хоменко О. В., Тимченко Д. О. Альтернативна енергетика як ключ до сталого розвитку Китаю та енергетичної незалежності України // Україна - Китай, 2017, № 3 .

\section{REFERENCES}

Bloomberg New Energy Finance (2019), Late Surge in Offshore Wind Financings Helps 2019 Renewables Investment to Overtake 2018, available at: https:// about.bnef.com/blog/late-surge-in-offshore-wind-financings-helps-2019-renewables-investment-to-overtake-2018/

Enerdata (2017), Global Energy Statistical Yearbook 2017, available at: https:// yearbook.enerdata.net/2016/

Enerdata (2019), Global Energy Statistical Yearbook 2019, available at: https:// www.enerdata.net/publications/world-energy-statistics-supply-and-demand.html

IEA (2019), IEA-PVPS - Trends in Photovoltaic Applications 2019, available at: https://www.dropbox.com/s/t6j1vw8dmd05kv6/Iea-pvps_report_2019.pdf

IRENA (2019), Renewable capacity statistics 2019, International Renewable Energy Agency (IRENA), Abu Dhabi, available at: https://www.irena.org/publications/2019/Mar/Renewable-Capacity-Statistics-2019

Khomenko, O. V. \& Tymchenko, D. O. (2017), “Al’ternatyvna enerhetyka yak klyuch do staloho rozvytku Kytayu ta enerhetychnoyi nezalezhnosti Ukrayiny", Ukrayina - Kytay, pp. 98-103.

Liu, J. (2019), "China's renewable energy law and policy: A critical review", Renewable and Sustainable Energy Reviews, 99, pp. 212-19.

REN21 (2019), Renewables 2019 Global Status Report, available at: https:// www.ren21.net/wp-content/uploads/2019/05/gsr_2019_full_report_en.pdf

World Economic Forum (2020), Global Innovations from the Energy Sector 2010-2020, available at: http://www3.weforum.org/docs/WEF_Transformational_ Energy_Innovations_2010_2020.pdf

Zhao, Z., Zhang, S.-Y., Hubbard, B. \& Yao, X. (2013), "The emergence of the solar photovoltaic power industry in China", Renewable and Sustainable Energy Reviews, 21, pp. 229-36.

Zhu, T. \& Wang, L. (2019), "Characteristics of China's Energy Transformation", In T. Zhu, \& L. Wang, State Energy Transition, pp. 233-66, Chinese Academy of Social Sciences, Beijing. 


\section{ЕНЕРГЕТИЧНА ТРАНСФОРМАЦІЯ В КИТАЇ: ШЛЯХ ДО ГЛОБАЛЬНОГО ЛІДЕРСТВА В АЛЬТЕРНАТИВНІЙ ЕНЕРГЕТИЦІ}

О. В. Дроботюк, В. Є. Осадчук, В. О. Шайдецька

Глобальні проблеми зміни клімату, дефіцит природних ресурсів та потреба забезпечити сталий розвиток призвели до трансформації енергетичного сектору. У цьому контексті збалансоване управління природними ресурсами є одним із пріоритетних завдань урядів країн світу. Альтернативна енергетика - це шлях подолання дефіциту традиційних джерел енергії та зменшення викидів вуглекислого газу у довкілля. Саме розвиток альтернативної енергетики та доступ до дешевих, надійних, стійких та сучасних джерел енергії є однією із сімнадцяти цілей сталого розвитку, прийнятих ООН у 2015 році.

Швидкий економічний розвиток Китаю, який розпочався 40 років тому всебічною політикою реформ, призвів до зростання попиту на енергію. Починаючи з 1978 року, уряд Китаю ввів багато заходів для залучення інвестицій та реструктуризації енергетичного сектору. У 2018 році, за даними міжнародної організації Enerdata, Китай посідає перше місце у виробництві, продажах та споживанні енергії, випередивши США та Японію.

Безумовно, темпи зростання та розмір економіки Китаю потребують значного споживання енергії, тому поряд із збереженням традиційних джерел енергії Китай активно збільшує виробництво електроенергії з відновлюваних джерел, переважно сонячної та вітрової. Статистика свідчить, що Китай посідає провідні позиції в галузі відновлюваної енергетики і $€$ найбільшим інвестором у неї. Китай має найвищу частку споживання сонячної енергії у світі, а енергія вітру є другою за важливістю відновлюваною енергією в країні. Китай володіє значними інвестиційними ресурсами для подальшого розвитку альтернативної енергетики, що відповідає національній меті.

У статті представлені ретроспективний аналіз трансформації енергетичного сектору Китаю, характеристика сучасного стану виробництва та споживання традиційної й альтернативної енергії.

Ключові слова: Китай, зелена енергетика, альтернативна енергетика, трансформація енергії, зелене зростання, економіка $з$ низьким вмістом вуглецю

\section{ЭНЕРГЕТИЧЕСКАЯ ТРАНСФОРМАЦИЯ В КИТАЕ: ПУТЬ К ГЛОБАЛЬНОМУ ЛИДЕРСТВУ В АЛЬТЕРНАТИВНОЙ ЭНЕРГЕТИКЕ}

О. В. Дроботюк, В. Е. Осадчук, В. А. Шайдецкая

Глобальные проблемы изменения климата, дефицит природных ресурсов и потребность обеспечить устойчивое развитие привели к трансформации энергетического сектора. В этом контексте сбалансированное управление природными ресурсами является одной из приоритетных задач правительств стран мира. Альтернативная энергетика - это путь преодоления дефицита традиционных источников энергии и уменьшение выбросов углекислого газа в окружающую среду. Именно развитие альтернативной энергетики и доступ к дешевым, надежным, устойчивым и современным источникам энергии является одной из семнадцати целей устойчивого развития, принятых ООН в 2015 году.

Быстрое экономическое развитие Китая, которое началось 40 лет назад со всесторонней политики реформ, привело к росту спроса на энергию. Начиная с 1978 года правительство Китая ввело множество мер для привлечения инвестиций и реструктуризации энергетического сектора. В 2018 году, по данным международной организации Enerdata, Китай занимает первое место в производстве, продажах и потреблении энергии, опередив США и Японию.

Безусловно, темпы роста и размер экономики Китая требуют значительного потребления энергии, поэтому наряду с сохранением традиционных источников энергии Китай активно увеличивает производство электроэнергии из возобновляемых 
источников, преимущественно солнечной и ветровой. Статистика свидетельствует, что Китай занимает лидирующие позиции в области возобновляемой энергетики и является крупнейшим инвестором в нее. Китай имеет самую высокую долю потребления солнечной энергии в мире, а энергия ветра является второй по важности возобновляемой энергией в стране. Китай владеет значительными инвестиционными ресурсами для дальнейшего развития альтернативной энергетики, соответствующего национальной цели.

В статье представлены ретроспективный анализ трансформации энергетического сектора Китая, характеристика современного состояния производства и потребления традиционной и альтернативной энергии.

Ключевые слова: Китай, зеленая энергетика, альтернативная энергетика, энергетическая трансформация, зеленый рост, экономика с низким содержанием углерода

Стаття надійшла до редакиії 22.05.2020 